
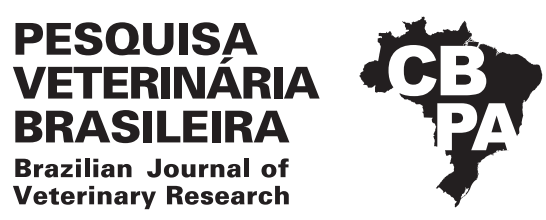

Pesq. Vet. Bras. 38(7):1286-1292, julho 2018 DOI: 10.1590/1678-5150-PVB-5225

Original Article

ISSN 0100-736X (Print)

ISSN 1678-5150 (Online)

\title{
Gastrointestinal and pulmonary nematodes in calves naturally infected in the cities of Botucatu and Manduri, in the Brazilian state of São Paulo ${ }^{1}$
}

\author{
Marcela C. Cezaro², José H. Neves², José R.L.M. Cury², Felipe M. Dalanezi³, \\ Raphaela M. Oliveira², João C.P. Ferreira ${ }^{3}$, Vitoldo A.K. Neto ${ }^{2}$ \\ and Elizabeth M.S. Schmidt ${ }^{2 *}$
}

\begin{abstract}
Cezaro M.C., Neves J.H., Cury J.R.L.M., Dalanezi F.M., Oliveira R.M., Ferreira J.C.P., Neto V.A.K. \& Schmidt E.M.S. 2018. Gastrointestinal and pulmonary nematodes in calves naturally infected in the cities of Botucatu and Manduri, in the Brazilian state of São Paulo. Pesquisa Veterinária Brasileira 38(7):1286-1292. Departamento de Clínica Veterinária, Faculdade de Medicina Veterinária e Zootecnia, Universidade Estadual Paulista, Rua Prof. Walter Mauricio Correa s/n, Bairro Unesp, Campus de Botucatu, Cx. Postal 560, Botucatu, SP 18618-681, Brazil. E-mail: bethschmidt@fmvz.unesp.br

This study aimed to determine the occurrence of gastrointestinal and pulmonary parasites in calves and to evaluate seasonal and age patterns in parasitism. For this, we used 140 clinically healthy crossbreed calves (two to 12 months old) that belonged to two private farms in the municipalities of Botucatu ( $\mathrm{n}=53$ ) and Manduri ( $\mathrm{n}=87)$, São Paulo state, Brazil. The calves were monitored for 12 months (from September 2014 to August 2015). Fecal samples were collected directly from the rectum every three months. Fecal egg counts were determined using the modified McMaster technique with a sensitivity of 50 eggs per gram of feces (EPG). Coproculture was performed on pooled samples to identify Strongylida infective larvae. First-stage larvae of Dictyocaulus viviparus were extracted by a modified Baermann method. The data showed non-normal distribution (Shapiro-Wilk) and the nonparametric Kruskall-Wallis test was employed to evaluate the EPG data by seasons and age groups. Dunn's post-test was used for multiple comparisons $(P<0.05)$. The calves from Manduri farm showed significantly higher fecal egg counts $(P<0.0001)$ in the winter when compared to other seasons. At Botucatu farm, young calves (2-3 months old) showed significantly higher EPG than old calves (8-12 months) $(P=0.01)$. The prevalence and overall mean of animals positive for Strongylida type-eggs were $81.1 \%$ and 340 in Botucatu, respectively, versus $83.9 \%$ and 854 in Manduri, respectively. Furthermore, we found Strongyloides spp., Moniezia spp., and Trichuris spp. eggs and Eimeria spp. oocysts. The prevalent genera in all coprocultures in decreasing order were: Cooperia spp., Haemonchus spp., Oesophagostomum spp., and Trichostrongylus spp. First-stage larvae of Dictyocaulus viviparus were found only in Botucatu farm samples throughout the year, except in spring.
\end{abstract}

INDEX TERMS: Gastrointestinal, pulmonary, lung, nematodes, naturally infected, cattle, Brazil, Dictyocaulus viviparous, parasitoses.

\footnotetext{
${ }^{1}$ Received on May 31, 2017.

Accepted for publication on June 13, 2017.

${ }^{2}$ Programa de Pós-Graduação em Medicina Veterinária, Departamento de Clínica Veterinária, Faculdade de Medicina Veterinária e Zootecnia (FMVZ), Universidade Estadual Paulista (Unesp), Rua Prof. Walter Mauricio Correa s/n, Bairro Unesp, Campus de Botucatu, Cx. Postal 560, Botucatu, SP 18618681, Brazil. *Corresponding author: bethschmidt@fmvz.unesp.br

${ }^{3}$ Programa de Pós-Graduação em Biotecnologia Animal, Departamento de Reprodução Animal e Radiologia Veterinária, Faculdade de Medicina Veterinária e Zootecnia (FMVZ), Universidade Estadual Paulista (Unesp), Rua Prof. Walter Mauricio Correa s/n, Bairro Unesp, Campus de Botucatu, Cx. Postal 560, Botucatu, SP 18618-681.
}

RESUMO.- [Nematódeos gastrintestinais e pulmonares em bezerros naturalmente infectados nos municípios de Botucatu e Manduri, estado de São Paulo.] 0 objetivo deste estudo foi investigar os parasitas gastrintestinais e pulmonares que acometem bezerros bem como a possível influência de fatores climáticos e da idade no parasitismo. Para isso, durante um período de 12 meses (setembro de 2014 a agosto de 2015), amostras de fezes foram coletadas a cada três meses diretamente da ampola retal de 140 bezerros 
mestiços (dois a 12 meses de idade), clinicamente saudáveis, pertencentes a duas propriedades leiteiras localizadas nos municípios de Botucatu $(n=53)$ e Manduri $(n=87)$, estado de São Paulo. Realizou-se a contagem de ovos por grama de fezes pela técnica de McMaster modificada com sensibilidade de 50 ovos por grama de fezes (OPG). Coproculturas foram realizadas em pool de amostras para a obtenção das larvas infectantes $\left(\mathrm{L}_{3}\right)$. Larvas de primeiro estágio de Dictyocaulus viviparus foram recuperadas pela modificação da técnica de Baermann. Os dados não se apresentaram normalmente distribuídos (Shapiro-Wilk), e o teste não paramétrico de Kruskal-Wallis foi utilizado para avaliar os dados de OPG em relação às estações do ano e faixa etária. Para comparações múltiplas, empregou-se o pós-teste de Dunn. Foi verificado que em Manduri, no inverno, houve um aumento significativo $(P<0,0001)$ na contagem de OPG em comparação as demais estações do ano. Em Botucatu, os animais com dois a três meses de idade apresentaram maiores contagens de OPG quando comparados aos animais de oito a 12 meses de idade $(P=0,01)$. A prevalência e a média global de animais positivos para ovos do tipo Strongylida, em Botucatu, foi de $81,1 \%$ e 340, respectivamente, e em Manduri foi de 83,9\% e 854, respectivamente. Em adição, de maneira geral, foram encontrados ovos de Strongyloides spp., Moniezia spp., Trichuris spp. e oocistos de Eimeria spp. Foram recuperadas, em ordem de prevalência, larvas infectantes de Cooperia spp., Haemonchus spp., Oesophagostomum spp. e Trichostrongylus spp. Larvas de $D$. viviparus foram recuperadas somente na propriedade de Botucatu durante todo o ano, com exceção da primavera.

TERMOS DE INDEXAÇÃO: Nematódeos, gastrointestinal, pulmonar, bezerros, infecção natural, bovinos, Brasil, Dictyocaulus viviparus, parasitoses.

\section{INTRODUCTION}

In Brazil, the epidemiology of parasitic infections in bovines was assessed by several authors, in diverse states, including in São Paulo (SP) (Oliveira \& Matsumoto 1985, Oliveira 1988, Bresciani et al. 2001, Borges et al. 2001, Landim et al. 2001), Minas Gerais (MG) (Furlong et al. 1985, Lima 1998, Araujo \& Lima 2005, Santos et al. 2010) and Rio de Janeiro (RJ) (Duarte et al. 1982, Pimentel Neto \& Fonseca 2002). Dealing more specifically with gastrointestinal and pulmonary nematodes, in general, the genera and/or species observed were: Cooperia spp., Haemonchus spp., Trichostrongylus spp., Oesophagostomum spp., Bunostomum spp., Agriostomum wryburgi, Capillaria bovis, Strongyloides papillosus, Trichuris discolor, and less commonly Ostertagia spp. and Dictyocaulus viviparus.

Epidemiological studies of parasites supply relevant data. In addition to mapping parasites that are endemic in a specific area, it is possible to investigate and evaluate changes that occur across time such as: adaptations, the appearance and/or re-emergence of species, emergence of resistance to anthelmintics, and, mainly, the development of strategies that could aid in the control and prevention of these infections.

Thus, the present work aimed to investigate and supply epidemiological data on gastrointestinal and pulmonary parasites in naturally infected calves, by means of coproparasitological analyses, and to observe whether the parasitic infections can present a behavior that is seasonal, and/or age-based.

\section{MATERIALS AND METHODS}

The present study was approved by the Committee for the Ethical Use of Animals (protocol 18/2015 - CEUA) of FMVZ, Unesp, Campus of Botucatu.

The field work was conducted on two dairy farm properties located in the municipality of Botucatu (latitude South $22^{\circ} 91^{\prime} 46^{\prime \prime}$, longitude West $48^{\circ} 35^{\prime} 25^{\prime \prime}$ ), and Manduri (latitude south $23^{\circ} 02^{\prime} 51^{\prime \prime}$; longitude west $\left.49^{\circ} 18^{\prime} 42^{\prime \prime}\right)$, in the state of São Paulo, Brazil. The climatic data referent to mean temperature $\left({ }^{\circ} \mathrm{C}\right)$ and accumulated rainfall $(\mathrm{mm})$ for the Botucatu property, were obtained at the Environmental Sciences Area in the Department of Natural Resources, at the School of Agronomic Sciences, Unesp, Campus of Botucatu, located $22.5 \mathrm{~km}$ from this property. The data for Manduri were obtained via the Agrometeorological and Hydrological Portal for the state of São Paulo (Portal Agrometeorológico e Hidrológico do Estado de São Paulo 2016) from the meteorological station located at Ataliba Leonel Farm, at the edge of the urban zone of this municipality, belonging to the Coordinator of Integral Technical Assistance (CATI), of the Secretary of Agriculture and Food Distribution for the state of São Paulo, three Km from the study location.

The 140 clinically healthy calves were crossbred (Holstein x Gir), divided into 56 males and 84 females, aged from two to 12 months. The animals were vaccinated against foot-and-mouth disease and females (from three to eight months) were immunized against brucellosis in accord with current law in relation to the National Program for Animal Health in Brazil (Brasil 2009). The managements of calves were similar between the two properties. The animals were weaned gradually at approximately six months of age and they were maintained in a pasture of Brachiaria spp. On the Botucatu property, the animals were supplemented with concentrate throughout the year. However, in Manduri, the calves received supplementation of corn silage only in winter. In relation to anthelmintic use, the properties did not follow a deworming protocol. In the period prior to the collections (30 days) and during the study there was no treatment of the animals.

Four collections of feces were carried out on each property during a 12-month period: between the spring of 2014 and the winter of 2015. Each procedure was performed in one season of the year. The collection of feces from each animal was made directly from the rectum with identified plastic bags. The samples were conditioned in a Styrofoam box with ice and sent to the Laboratory of Animal Parasitic Diseases at the Veterinary Teaching Hospital of the School of Veterinary Medicine (FMVZ), Unesp, Campus of Botucatu for analysis. The modified McMaster technique (Gordon \& Whitlock 1939) was employed for the counting of Strongylida type-eggs per gram of feces (EPG) with sensitivity of 50 EPG. When eggs and/or oocysts from other parasites were encountered, their presence was indicated. The coprocultures (Roberts \& O'Sullivan 1950) were accomplished in pooled samples, by property, in each collection. Approximately $2 \mathrm{~g}$ of feces were collected from each animal and were mixed with samples from other animals in a plastic receptacle with a lid. The pool of samples was macerated with distilled water and mixed with sterilized wood shavings, at the approximate proportion of two parts of wood shavings per one part of feces. The receptacles were filed with the mixture to $3 / 4$ of their capacity. The coprocultures were maintained at $27^{\circ} \mathrm{C}$ for seven days and when necessary were humidified. After seven days, the larvae $\left(\mathrm{L}_{3}\right)$ were collected. The $\mathrm{L}_{3}$ were identified according to the genus/specie based on the morphological and morphometric characteristics, namely: format of the cranial and caudal extremities, format of the esophagus and measurement of the total length of the larva and of the sheath tail (Ueno \& Gonçalves 
1998, Amarante 2011, Van Wyk \& Mayhew 2013). In the case of the genus Haemonchus, the $\mathrm{L}_{3}$ were differentiated in $H$. placei and $H$. similis, according to the measurement (mean \pm standard error) of the total larval length $(784.6 \pm 2.3 \mu \mathrm{m}, 611.1 \pm 5.4 \mu \mathrm{m}$ respectively) and of the sheath tail $(99.2 \pm 0.7 \mu \mathrm{m}, 57.3 \pm 0.8 \mu \mathrm{m}$ respectively) (Santiago 1968, Amarante 2011). Fecal first larval stage (L1) of D. viviparus was extracted by a modified Baermann method, described by Rugai et al. (1954). The first-stage larvae of D. viviparus were identified by its morphological characteristics, namely: slightly tapered tails with rounded ends. Additionally, the intestinal cells of the larvae are packed with nutrient granules (Anderson 2000). When positive, the result was given as the quantity of larvae per field (objective 10x).

The statistical analysis was performed via the software GraphPad Prism version 6 for Windows (GraphPad Software Inc., San Diego, CA, USA). The EPG results of animals from the properties of Botucatu and Manduri were analyzed according to the season of the year (spring, summer, autumn, and winter) and age group (two to three, four to seven, and eight to 12 months old) of the calves. The descriptive analysis of the data was interpreted through medians, interquartile intervals (25-75\%) and minimum and maximum values. All variables were first assessed for normality using the Shapiro-Wilk test. The nonparametric Kruskal-Wallis test was used to compare the data. Dunn's post-test was used for multiple comparisons as the data was not normally distributed. Statistical significance was set at $P<0.05$ for all analyses.

\section{RESULTS}

The mean temperature and monthly accumulated rainfall that were observed during the study period are presented in Figure 1 and 2. The global temperature means for

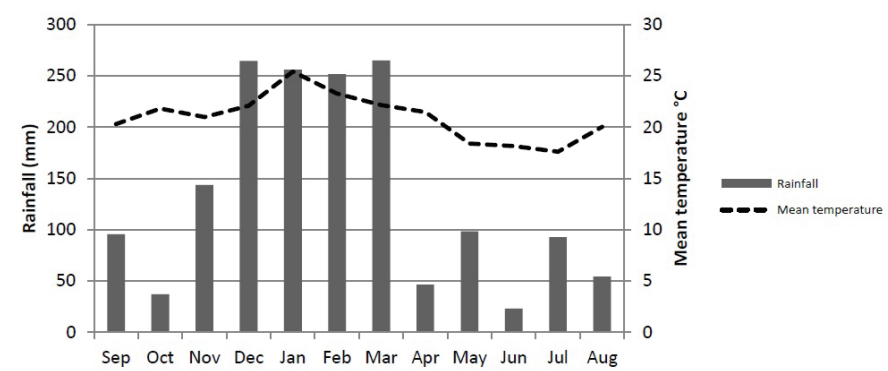

Fig.1. Mean temperature and accumulated monthly rainfall in the municipality of Botucatu/SP, Brazil, during the experimental period from September 2014 to August 2015.

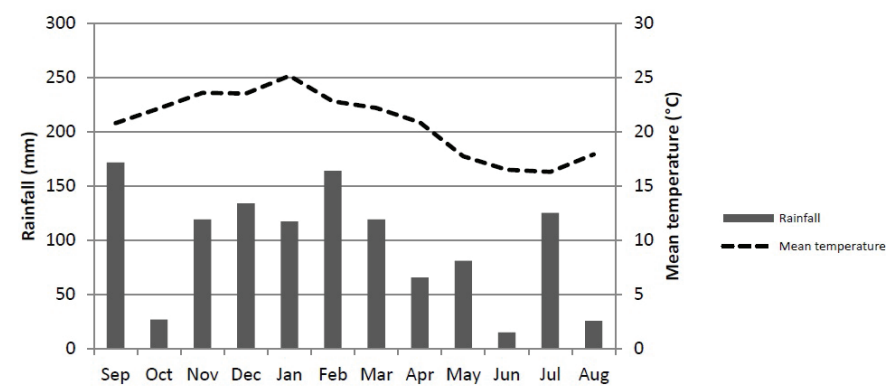

Fig.2. Mean temperature and accumulated monthly rainfall in the municipality of Manduri/SP, Brazil, during the experimental period from September 2014 to August 2015.
Botucatu and Manduri were 21 and $20.3^{\circ} \mathrm{C}$, respectively. For Botucatu and Manduri, the highest and lowest mean temperatures were registered in the months of January $\left(25.4\right.$ and $25.1^{\circ} \mathrm{C}$ ) and July $\left(17.6\right.$ and $\left.16.3^{\circ} \mathrm{C}\right)$ respectively. In relation to monthly accumulated precipitation, the global mean was $135.7 \mathrm{~mm}$ for Botucatu and $103.7 \mathrm{~mm}$ for Manduri. The highest precipitations were observed in the month of September of 2014 in Manduri and between November of 2014 and March of 2015 in both.

The results of EPG counts from calves infected naturally by gastrointestinal nematodes in the four seasons of the year, on the properties in Botucatu and Manduri, SP, are presented in Figure 3. On the Botucatu property there was no significant difference $(P=0.16)$ in $E P G$ counts in relation to the four seasons of the year. The same did not occur on the Manduri property, since it was observed that in winter there was a peak in the EPG count with significant increase $(P=0.0006)$ in relation to the other seasons.

The data were also analyzed according to age group of calves on the Botucatu and Manduri properties, and the results are presented in Figure 4. In the municipality of Botucatu, the animals aged up to three months presented EPG results significantly higher than those from calves eight to 12 months of age $(P=0.01)$. On the other hand, the EPG count from calves belonging to the Manduri property did not differ significantly in relation to age $(P=0.89)$.

The prevalences (\%) of EPG positive animals observed in Botucatu and Manduri/SP, in different seasons of the
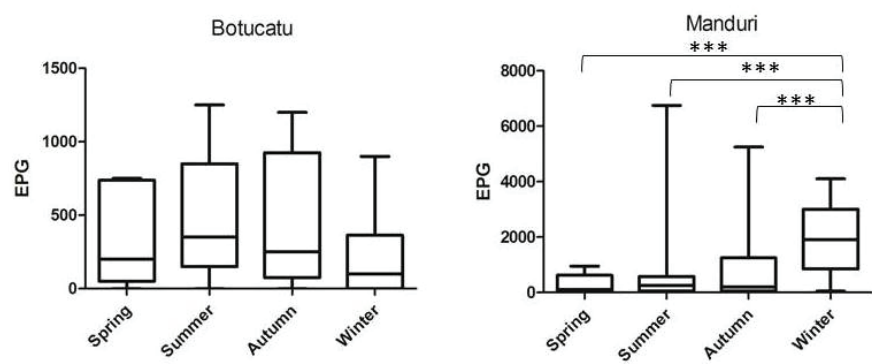

Fig.3. Count of eggs per gram of feces (EPG) in calves naturally infected in different seasons of the year on a dairy farm properties located in the municipalities of Botucatu and Manduri/SP, Brazil, from September 2014 to August 2015. Horizontal lines represent the median and interquartile intervals. ${ }^{* * *} P<0.0001$.
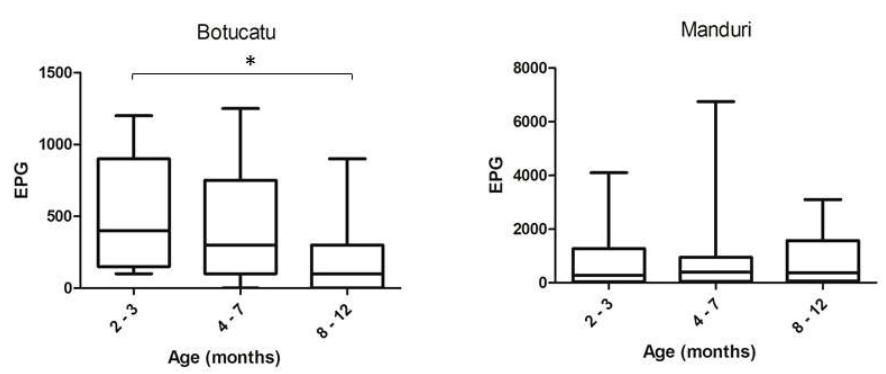

Fig.4. Count of eggs per gram of feces (EPG) in naturally infected calves divided into age groups on a dairy farm properties located in the municipalities of Botucatu and Manduri/SP, Brazil, from September 2014 to August 2015. Horizontal lines represent the median and interquartile intervals. ${ }^{*} P=0.01$. 
year, are presented in Table 1. As to the degree of infection observed in animals, when divided into low EPG $(\leq 200)$ and high EPG $(>200)$ according to the threshold proposed by Vercruysse \& Claerebout (2001), the respective prevalences observed in Botucatu were 56.6 and 43.4\%. Meanwhile in Manduri, the prevalences were $41.4 \%$ and $58.6 \%$ for low and high EPG respectively. When the EPG infection degree was categorized into one additional class, namely low $(\leq 200)$, moderate $(>200$ and $\leq 700)$ and high $(>700)$, as described by Pfukenyi et al. (2007), the respective observed prevalences in Botucatu were 56.6, 20.75, and 22.6\%, while those in Manduri were: 41.4, 25.3, and 33.3\%. The global EPG mean found throughout the experimental period on the Botucatu property was 340, whereas the EPG count in Manduri was 854.

The Strongyloides spp. eggs were counted separately, revealing a significant age difference in which the Botucatu property presented a higher number of eggs in the younger animals (two to three months old) when compared to animals from the other age groups $(P=0.001)$ (Fig.5). However, the same was not observed on the Manduri property, where the number of Strongyloides spp. eggs was relatively low throughout the period, given that of the 87 animals evaluated, only four animals presented eggs of this parasite, and did not differ significantly in relation to the age $(P=0.51)$. Eggs from other parasites, such as: Moniezia spp., Trichuris spp., and oocysts from Eimeria spp. were observed by the modified McMaster technique. The prevalences for the Botucatu and Manduri properties are presented in Table 2.

The results of reading and identification of $\mathrm{L}_{3}$ are presented in Table 3. The predominant genera in all the coprocultures from the Botucatu and Manduri properties were Cooperia spp., followed by Haemonchus placei, Oesophagostomum spp. and Trichostrongylus spp. Haemonchus similis was identified only on the Manduri site, at a prevalence of $1 \%$ in autumn and in winter. On the Botucatu property, in the coproculture performed in winter, the presence of Strongyloides spp. $\mathrm{L}_{3}$ was observed. The springtime coproculture accomplished in Manduri presented excessive fungal growth, which may have provoked the degeneration of larvae, thus precluding their successful recovery and identification.

The presence of $\mathrm{L}_{1}$ from Dictyocaulus viviparus was observed only on the Botucatu property. When the fecal sample quantity was limited, preference was given to the EPG exam; therefore, in the summer season in Botucatu, out of a total of 11 animals, only seven were evaluated by a modified Baermann method. The same occurred on the Manduri property, given that only 73 of the 87 calves evaluated were tested for the study of $\mathrm{L}_{1}$ from $D$. viviparus in feces, but all the animals presented negative results.

The prevalences in relation to seasons of the year in Botucatu showed that the presence of D. viviparus occurred through the entire year, except spring, in low levels of infection (rare to two specimens per field at 10x objective). In autumn there was a $50 \%$ prevalence $(5 / 10)$ of positive animals, in winter $35 \%(7 / 20)$, and in summer $28.5 \%(2 / 7)$ of animals presented larvae of the pulmonary parasite. The age group of positive animals ranged from three to 11 months.

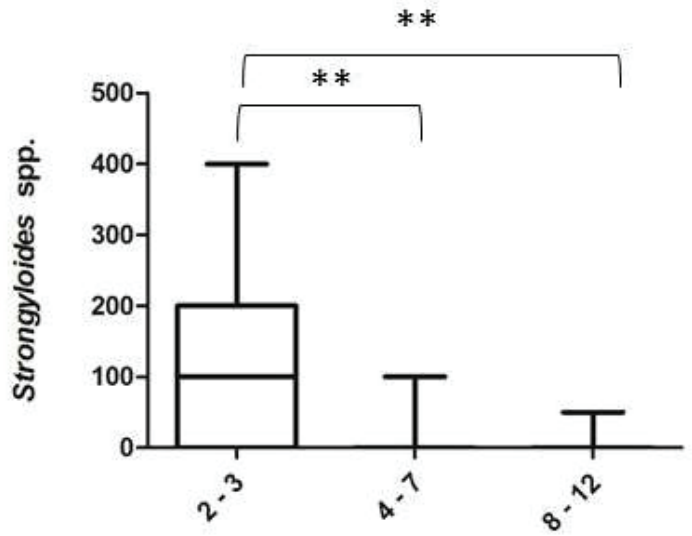

Fig.5. Count of Strongyloides spp. eggs per gram of feces (EPG) in naturally infected calves divided into age groups on a property in Botucatu, SP, Brazil, from September 2014 to August 2015. Horizontal lines represent the median and interquartile intervals. ** $P=0.001$.

Table 1. Prevalence (\%) of calves positive in egg count per gram of feces (EPG) in different seasons of the year in dairy farm properties located in the municipalities of Botucatu and Manduri/SP, Brazil, from September 2014 to August 2015

\begin{tabular}{ccc}
\hline Season & Botucatu (\%) & Manduri (\%) \\
\hline Spring & $91.6(11 / 12)$ & $66.6(6 / 9)$ \\
Summer & $91(10 / 11)$ & $79(30 / 38)$ \\
Autumn & $80(8 / 10)$ & $88(22 / 25)$ \\
Winter & $70(14 / 20)$ & $100(15 / 15)$ \\
Overall & $81.1(43 / 53)$ & $83.9(73 / 87)$
\end{tabular}

Prevalences (\%) of EPG positive animals/total animals.

Table 2. Prevalence (\%) of eggs and oocysts of parasites in calves evaluated in different seasons of the year in dairy farm properties located in the municipalities of Botucatu and Manduri/SP, Brazil, from September 2014 to August 2015

\begin{tabular}{ccccc}
\hline \multirow{2}{*}{ Season } & Property & $\begin{array}{c}\text { Moniezia spp. } \\
(\%)\end{array}$ & $\begin{array}{c}\text { Trichuris spp. } \\
(\%)\end{array}$ & $\begin{array}{c}\text { Eimeria spp. } \\
(\%)\end{array}$ \\
\hline \multirow{2}{*}{ Spring } & Botucatu & 8.3 & 0 & 83.3 \\
& Manduri & 11.1 & 11.1 & 0 \\
Summer & Botucatu & 36.3 & 0 & 54.5 \\
& Manduri & 7.9 & 0 & 47.3 \\
\multirow{5}{*}{ Autumn } & Botucatu & 0 & & 20 \\
& Manduri & 8 & 0 & 76 \\
& & & 0 & 80 \\
Winter & Botucatu & 5 & 0 & 33.3 \\
& Manduri & 13.3 & 6.6 & 64.1 \\
& & & & 48.3
\end{tabular}


Table 3. Prevalence $(\%)$ of infective larvae $\left(L_{3}\right)$ from gastrointestinal nematodes recovered from coprocultures accomplished in a pool of samples from calves naturally infected by season of the year in dairy farm properties, Botucatu and Manduri/SP, Brazil, from September 2014 to August 2015

\begin{tabular}{|c|c|c|c|c|c|c|c|c|c|c|}
\hline \multicolumn{11}{|c|}{ Infective larvae $\left(\mathrm{L}_{3}\right)$} \\
\hline \multirow[t]{2}{*}{ Season } & \multicolumn{2}{|c|}{$\begin{array}{c}\text { Cooperia spp. } \\
(\%)\end{array}$} & \multicolumn{2}{|c|}{$\begin{array}{c}\text { Haemonchus placei } \\
(\%)\end{array}$} & \multicolumn{2}{|c|}{$\begin{array}{c}\text { Haemonchus similis } \\
(\%)\end{array}$} & \multicolumn{2}{|c|}{$\begin{array}{c}\text { Oesophagostomum spp. } \\
(\%)\end{array}$} & \multicolumn{2}{|c|}{$\begin{array}{c}\text { Trichostrongylus spp. } \\
(\%)\end{array}$} \\
\hline & B & $\mathrm{M}$ & B & $\mathrm{M}$ & B & M & B & $\mathrm{M}$ & B & $M$ \\
\hline Spring & 60 & - & 39 & - & - & - & - & - & 1 & - \\
\hline Summer & 94 & 88 & 3 & 10 & - & - & 3 & 2 & - & - \\
\hline Autumm & 93 & 58 & 6 & 27 & - & 1 & 1 & 13 & - & 1 \\
\hline Winter & 63 & 76 & 21 & 20 & - & 1 & 14 & 2 & 2 & 1 \\
\hline
\end{tabular}

$\overline{\mathrm{B}=\text { Botucatu }}, \mathrm{M}=$ Manduri.

\section{DISCUSSION}

The conditions of temperature and rainfall observed during the period were adequate for the survival and development of up to two specimens of infective larvae of parasites throughout the year. Furthermore, in a general manner, the rainfall delimited two distinct periods, one characterized by abundant rains in the hotter months and the other with less precipitation in the colder months. In the state of MG, similar climatic conditions also enabled the development of larvae in the environment and the contamination of bovines by infective third-stages throughout the year (Lima 1998, Araujo \& Lima 2005).

According to Oliveira (1988) in the city of São Carlos, state of SP, Lima (1998) in the municipality de Governador Valadares, and of Araujo \& Lima (2005) in the municipality of Carandaí, both in MG, the highest EPG counts in calves were obtained in the rainy season. However, on the Manduri property, there was a significant EPG peak in the winter, a season characterized by lower precipitation. Despite the supplementation of animals with corn silage in winter, this EPG peak may have been attributable to the unfavorable nutritional conditions of this season, when there is a scarcity and reduced quality of pasture available to the animals. In Cambodia, Dorny et al. (2011) observed a significant relation in bovines that presented high EPG, which was associated with a poorer score on body condition in the dry season. In addition, Amarante \& Amarante (2016) commented that inadequate nutrition is frequently associated with an increase of EPG in ruminants in Brazil.

In relation to age group, on the Botucatu property, animals aged two to three months presented significantly higher EPG counts, possibly because they were exposed to a pasture highly contaminated with infective larvae at the same time they also had begun to use pasture as a food source. According to Herlich (1960) and Yazwinski \& Tucker (2006) the course of parasitic infections in calves is affected by age as immune competence develops against challenge infections. Lima (1998) in the state of MG, observed EPG of beef cattle extensively raised with a gradual increase starting from three months until one year of age. Additionally, in Mato Grosso do Sul, Catto \& Ueno (1981) when evaluating suckling and weaned zebu calves, observed that parasitism was more important in weaned animals, becoming more evident as the banimals came to utilize the pasture as the principal food source.

The same calves from two to three months of age, from the Botucatu property, presented Strongyloides spp. egg counts significantly higher in relation to the other age groups and, according to the investigation of Lima (1998) in MG, the Strongyloides spp. eggs are the first to be found in young animals, with a peak at two months of age. Keyyu et al. (2005) and Pfukenyi et al. (2007) when evaluating young and adult bovines verified that eggs and $\mathrm{L}_{3}$ of Strongyloides spp. were identified only in samples from calves. This fact may be attributed to the $\mathrm{L}_{3}$ transmammary transmission of this parasite and to the decreased parasite burden as animals age and develop immune competence (Anderson 2000, Thamsborg et al. 2017).

In general, in EPG, besides Strongylida type-eggs, eggs from Moniezia spp., Trichuris spp., Strongyloides spp., and oocysts from Eimeria spp., were also observed, as in previous investigations by Repossi Junior et al. (2006), and Freitas Junior et al. (2008) in the state of Espírito Santo, Brazil, Pfukenyi et al. (2007) in the Republic of Zimbabwe, Jimenéz et al. (2010) in Costa Rica, and Huang et al. (2014) in Taiwan.

The $\mathrm{L}_{3}$ from Cooperia spp., Haemonchus spp., Oesophagostomum spp. and Trichostrongylus spp. identified in coprocultures, were also found by Neves et al. (2014) in an investigation carried out in the state of SP, and Araujo \& Lima (2005) in the state of MG. Furthermore, they are in agreement with Holland et al. (2000) in Vietnam, and Pfukenyi et al. (2007) in the Republic of Zimbabwe.

D. viviparus have been identified previously in the states of SP (Oliveira \& Matsumoto 1985, Oliveira 1988, Borges et al. 2001, Landim et al. 2001), RJ (Duarte et al. 1982, Pimentel Neto \& Fonseca 2002), and MG (Furlong et al. 1985) by means of necropsies of young bovines. Additionally, in the state of RS, there was an outbreak of dictyocaulosis in 15 beef calves, aged five to seven months. The death of two of these animals demonstrates the importance of this parasitism in Brazil (Silva et al. 2005) and that D. viviparus is re-emerging in Botucatu. The calves with GI and lungworms in Botucatu and Manduri could be considered potential contaminators of pasture. These infected calves are susceptible to delayed development, decreased weight gain affecting the animal's welfare and production.

\section{CONCLUSIONS}

These findings provided and overview of the GI and pulmonary parasites infections in calves in a particular region of São Paulo state, which should be considered in differential diagnosis. 
The identification of $\mathrm{L}_{1}$ from Dictyocaulus viviparus indicates lungworm infection in calves in Botucatu throughout the year.

Acknowledgements.- Marcela Cristina de Cezaro gratefully acknowledges the financial support of CAPES/Brazil. We are also grateful to Viviana H.V. Aristizabal, Henry D.M. García, Nadino Carvalho and Prof. Dr. Alessandro F.T. Amarante for the help in the sample collection, laboratory analyses and collaboration during this study.

\section{REFERENCES}

Amarante A.F.T. 2011. Why is it important to correctly identify Haemonchus species? Revta Bras. Parasitol. Vet. 20 (4):263-268. <http://dx.doi. org/10.1590/S1984-29612011000400002><PMid:22166378>

Amarante A.F.T. \& Amarante M.R.V. 2016. Advances in the diagnosis of the gastrointestinal nematode infections in ruminants. Braz. J. Vet. Res. Anim. Sci. 53(2):127-137. <http://dx.doi.org/10.11606/issn.1678-4456. v53i2p127-137>

Anderson R.C. 2000. Nematode parasites of vertebrates: their development and transmission. CABI, Wallingford. 650p. <http://dx.doi.org/10.1079/ 9780851994215.0000>.

Araujo R.N. \& Lima W.S. 2005. Infecções helmínticas em um rebanho leiteiro na região Campo das Vertentes de Minas Gerais. Arq. Bras. Med. Vet. Zootec. 57(Suppl. 2):186-193. <http://dx.doi.org/10.1590/S010209352005000800009>

Borges F.A., Silveira D.M., Graminha E.B.N., Castagnolli K.C., Soares V.E., Nascimento A.A. \& Costa A.J. 2001. Fauna helmintológica de bovinos da região de Jaboticabal, Estado de São Paulo, Brasil. Semina, Ciênc. Agrárias 22:49-53.

Brasil 2009. Manual de Legislação. Programas Nacionais de Saúde Animal do Brasil, Ministério da Agricultura Pecuária e Abastecimento, Brasília, DF. 440p.

Bresciani K.D.S., Nascimento A.A., Costa A.J., Amarante A.F.T., Perri S.H.V. \& Lima L.G.F. 2001. Freqüência e intensidade parasitária de helmintos gastrintestinais em bovinos abatidos em frigorífico da região noroeste do Estado de São Paulo, SP, Brasil. Semina, Ciênc. Agrárias 22:93-97.

Catto J.B. \& Ueno H. 1981. Nematodioses gastrintestinais em bezerros zebus no Pantanal Matogrossense I. Prevalência, intensidade de infecção e variação estacional. Pesq. Agropec. Bras. 16:129-140.

Dorny P., Stoliaroff V., Charlier J., Meas S., Sorn S., Chea B., Holl D., Van Aken D. \& Vercruysse J. 2011. Infections with gastrointestinal nematodes, Fasciola and Paramphistomum in cattle in Cambodia and their association with morbidity parameters. Vet. Parasitol. 175(3/4):293-299. <http://dx.doi. org/10.1016/j.vetpar.2010.10.023><PMid:21071148>

Duarte M.J.F., Gomes P.A.C. \& Sant'Anna D.B. 1982. Prevalência e intensidade de infecção helmíntica em bezerros de Cantagalo, RJ, Brasil. Pesq. Agropec. Bras. 17:1521-1524.

Freitas Junior P.I., Demoner L.C., Avelar B.R., Nunes L.C., Donatele D.M. \& Martins I.V.F. 2008. Estudo parasitológico em bovinos leiteiros da microrregião do Caparaó, Espírito Santo, Brasil. Revta Port. Ciênc. Vet. 103:151-156.

Furlong J., Novas J.C.V. \& Cardoso Filho J.B. 1985. Parasitoses dos bovinos na região da zona da mata de Minas Gerais II. Incidência estacional de nematódeos pulmonares. Pesq. Agropec. Bras. 20:1409-1413.

Gordon H.McL. \& Whitlock H.V. 1939. A new technique for counting nematode eggs in sheep faeces. J. CSIRO 12:50-52.

Herlich H. 1960. Age resistance of cattle to nematodes of the gastrointestinal tract. J. Parasitol. 46(3):392-397. <http://dx.doi.org/10.2307/3275503> <PMid:14401262>

Holland W.G., Luong T.T., Nguyen L.A., Do T.T. \& Vercruysse J. 2000. The epidemiology of nematode and fluke infections in cattle in the Red River
Delta in Vietnam. Vet. Parasitol. 93(2):141-147.<http://dx.doi.org/10.1016/ S0304-4017(00)00363-0><PMid:11035232>

Huang C.C., Wang L.C., Pan C.H., Yang C.H. \& Lai C.H. 2014. Investigation of gastrointestinal parasites of dairy cattle around Taiwan. J. Microbiol. Immunol. Infect. 47(1):70-74. <http://dx.doi.org/10.1016/j.jmii.2012.10.004> $<$ PMid:23261308>

Jiménez A.E., Fernández A., Alfaro R., Dolz G., Vargas B., Epe C. \& Schnieder T. 2010. A cross-sectional survey of gastrointestinal parasites with dispersal stages in feces from Costa Rican dairy calves. Vet. Parasitol. 173(3/4):236246. <http://dx.doi.org/10.1016/j.vetpar.2010.07.013><PMid:20810217>

Keyyu J.D., Kyvsgaard N.C., Monrad J. \& Kassuku A.A. 2005. Epidemiology of gastrointestinal nematodes in cattle on traditional, small-scale dairy and large-scale dairy farms in Iringa district, Tanzania. Vet. Parasitol. 127(3/4):285-294. <http://dx.doi.org/10.1016/j.vetpar.2004.10.014> $<$ PMid:15710529>

Landim V.J.C., Costa A.J., Costa G.H.N., Rocha U.F., Barbosa O.F. \& Moraes F.R. 2001. Parasitic nematodes in weaned calves from the north-east region of São Paulo State, Brazil. Ars Vet. 17:42-50.

Lima W.S. 1998. Seasonal infection pattern of gastrointestinal nematodes of beef cattle in Minas Gerais State, Brazil. Vet. Parasitol. 74(2/4):203-214. <http://dx.doi.org/10.1016/S0304-4017(97)00164-7><PMid:9561708>

Neves J.H., Carvalho N., Rinaldi L., Cringoli G. \& Amarante A.F.T. 2014. Diagnosis of anthelmintic resistance in cattle in Brazil: a comparison of different methodologies. Vet. Parasitol. 206(3/4):216-226. <http://dx.doi. org/10.1016/j.vetpar.2014.10.015><PMid:25468021>

Oliveira G.P. 1988. Epidemiologia dos nematódeos gastrintestinais de bovinos leiteiros no município de São Carlos, Estado de São Paulo. Pesq. Agropec. Bras. 23:189-195.

Oliveira G.P. \& Matsumoto T. 1985. Prevalência e intensidade de infecção por helmintos em bovinos da bacia leiteira de São Carlos, São Paulo. Pesq. Agropec. Bras. 20:1415-1418.

Pfukenyi D.M., Mukaratirwa S., Willingham A.L. \& Monrad J. 2007. Epidemiological studies of parasitic gastrointestinal nematodes, cestodes and coccidia infections in cattle in the highveld and lowveld communal grazing areas of Zimbabwe. Onderstepoort J. Vet. Res. 74(2):129-142. <http://dx.doi. org/10.4102/ojvr.v74i2.132> <PMid:17883199>

Pimentel Neto M. \& Fonseca A.H. 2002. Epidemiologia das helmintoses pulmonares e gastrintestinais de bezerros em região de baixada do Estado do Rio de Janeiro. Pesq. Vet. Bras. 22(4):148-152. <http://dx.doi. org/10.1590/S0100-736X2002000400004>

Portal Agrometeorológico e Hidrológico do Estado de São Paulo 2016. Available at <http://ciiagro.org.br/diario/cperiodo> Access on Jan. 27, 2016.

Repossi Junior P.F., Barcellos M.P., Trivilin L.O., Martins I.V.F. \& Silva P.C.A.R. 2006. Prevalência e controle das parasitoses gastrintestinais em bezerros de propriedades leiteiras no município de Alegre, Espírito Santo. Revta Bras. Parasitol. Vet. 15:147-150.

Roberts F.H.S. \& O'Sullivan P.J. 1950. Methods for egg counts and larval cultures for strongyles infesting the gastro-intestinal tract of cattle. Aust. J. Agricult. Res. 1(1):99-102. <http://dx.doi.org/10.1071/AR9500099>

Rugai E., Mattos T. \& Brisola A.P. 1954. Nova técnica para isolar larvas de nematóides das fezes: modificação do Método de Baermann. Revta Inst. Adolfo Lutz 14:5-8.

Santiago M.A.M. 1968. Haemonchus Cobb, 1898 (Nematoda: Trichostrongylidae). Contribuição ao estudo da morfologia, biologia e distribuição geográfica das espécies parasitas de ovinos e bovinos no Rio Grande do Sul. Tese de Livre Docência, Universidade Federal de Santa Maria, Santa Maria, RS. 89p.

Santos T.R., Lopes W.D.Z., Buzulini C., Borges F.A., Sakamoto C.A.M., Lima R.C.A., Oliveira G.P. \& Costa A.J. 2010. Helminth fauna of bovines from the CentralWestern region, Minas Gerais State, Brazil. Ciência Rural 40(4):934-938. <http://dx.doi.org/10.1590/S0103-84782010005000040> 
Silva M.C., Barros R. \& Graça D.L. 2005. Surto de dictiocaulose em bovinos no município de Santa Maria, RS, Brasil. Ciência Rural 35(3):629-632. <http://dx.doi.org/10.1590/S0103-84782005000300022>

Thamsborg S.M., Ketzis J., Horii Y. \& Matthews J.B. 2017. Strongyloides spp. infections of veterinary importance. Parasitology 144(3):274-284. <http:// dx.doi.org/10.1017/S0031182016001116> <PMid:27374886>

Ueno H. \& Gonçalves P.C. 1998. Manual para Diagnóstico das Helmintoses de Ruminantes. Japan International Cooperation Agency, Tokyo. 140p.

Van Wyk J.A. \& Mayhew E. 2013. Morphological identification of parasitic nematode infective larvae of small ruminants and cattle: a practical lab guide. Onderstepoort J. Vet. Res. 80(1):1-14. <http://dx.doi.org/10.4102/ ojvr.v80i1.539><PMid:23718204>

Vercruysse J. \& Claerebout E. 2001. Treatment vs non-treatment of helminth infections in cattle: defining the threshold. Vet. Parasitol. 98(1/3):195-214. <http://dx.doi.org/10.1016/S0304-4017(01)004319> <PMid:11516586>

Yazwinski T.A. \& Tucker C.A. 2006. A sampling of factors relative to the epidemiology of gastrointestinal nematode parasites of cattle in the United States. Vet. Clin. N. Am., Food Anim. Pract. 22(3):501-527. <http://dx.doi. org/10.1016/j.cvfa.2006.07.005> <PMid:17071350> 